Check for updates

Cite this: RSC Adv., 2019, 9, 9770

Received 5th March 2019

Accepted 18th March 2019

DOI: 10.1039/c9ra01665a

rsc.li/rsc-advances

\section{Merging catalyst-free synthesis and iodine catalysis: one-pot synthesis of dihydrofuropyrimidines and spirodihydrofuropyrimidine pyrazolones $\uparrow$}

\author{
Ya-Yun Zheng, Kai-Xiang Feng, Ai-Bao Xia, (D)* Jie Liu, Cheng-Ke Tang, \\ Zhan-Yu Zhou and Dan-Qian Xu (DD*
}

A new and efficient one-pot strategy combining catalyst-free synthesis and iodine catalysis has been developed for the synthesis of dihydrofuropyrimidines and spirodihydrofuropyrimidine pyrazolones. This approach affords products in moderate to high yields (up to 96\%) with excellent diastereoselectivities (up to $>25: 1 \mathrm{dr}$ ). The reaction is simple to carry out and is metal-free.
Furo fused pyrimidines ${ }^{1}$ and dihydrofuro fused pyrimidines, ${ }^{2}$ derivatives of the pyrimidine species, ${ }^{3}$ are prevalent heteroaromatic core structures found in a broad variety of natural products, pharmaceuticals, and other biologically active molecules (Scheme 1). In particular, dihydrofuropyrimidine derivatives have shown a diverse range of useful biological and pharmacological activities such as anticancer, antiinflammatory, antiproliferative, and antirheumatic activities. The substituent group on the dihydrofuran moiety significantly influences the biological activity. However, efficient procedures for the synthesis of dihydrofuropyrimidines are not well developed. In 1987, Taylor et al. reported intramolecular Diels-Alder reactions of 1,2,4-triazines to synthesize dihydrofuro fused pyrimidines under very high temperature condition (Scheme 2A). ${ }^{4}$ Alternatively, dihydrofuropyrimidine derivatives can be prepared in relatively low yields from pre-synthesized 2,4dichloro-dihydrofuropyrimidines via further substitution reactions and coupling reactions (Scheme 2B). However, several steps are required to prepare highly functionalized starting materials with different furan groups. ${ }^{2 a, 5}$ Both of these methods have some well-known drawbacks: (a) harsh reaction conditions and the requirement of multistep synthetic sequences; (b) the use of poisonous or expensive reagents such as $\mathrm{COCl}_{2}, \mathrm{POCl}_{3}$, and transition metal Pd; and (c) low yields and limited substrate scope. Therefore, it is highly desirable to find an efficient and general synthetic methodology for the construction of various substituted dihydrofuropyrimidines, from easily accessible raw

Catalytic Hydrogenation Research Centre, State Key Laboratory Breeding Base of Green Chemistry-Synthesis Technology, Zhejiang University of Technology, Hangzhou, 310014, China. E-mail: xiaaibao@zjut.edu.cn; chrc@zjut.edu.cn $\dagger$ Electronic supplementary information (ESI) available: Experimental procedures, data, and NMR spectra of all compounds. CCDC 1893720 and 1893721. For ESI and crystallographic data in CIF or other electronic format see DOI: 10.1039/c9ra01665a

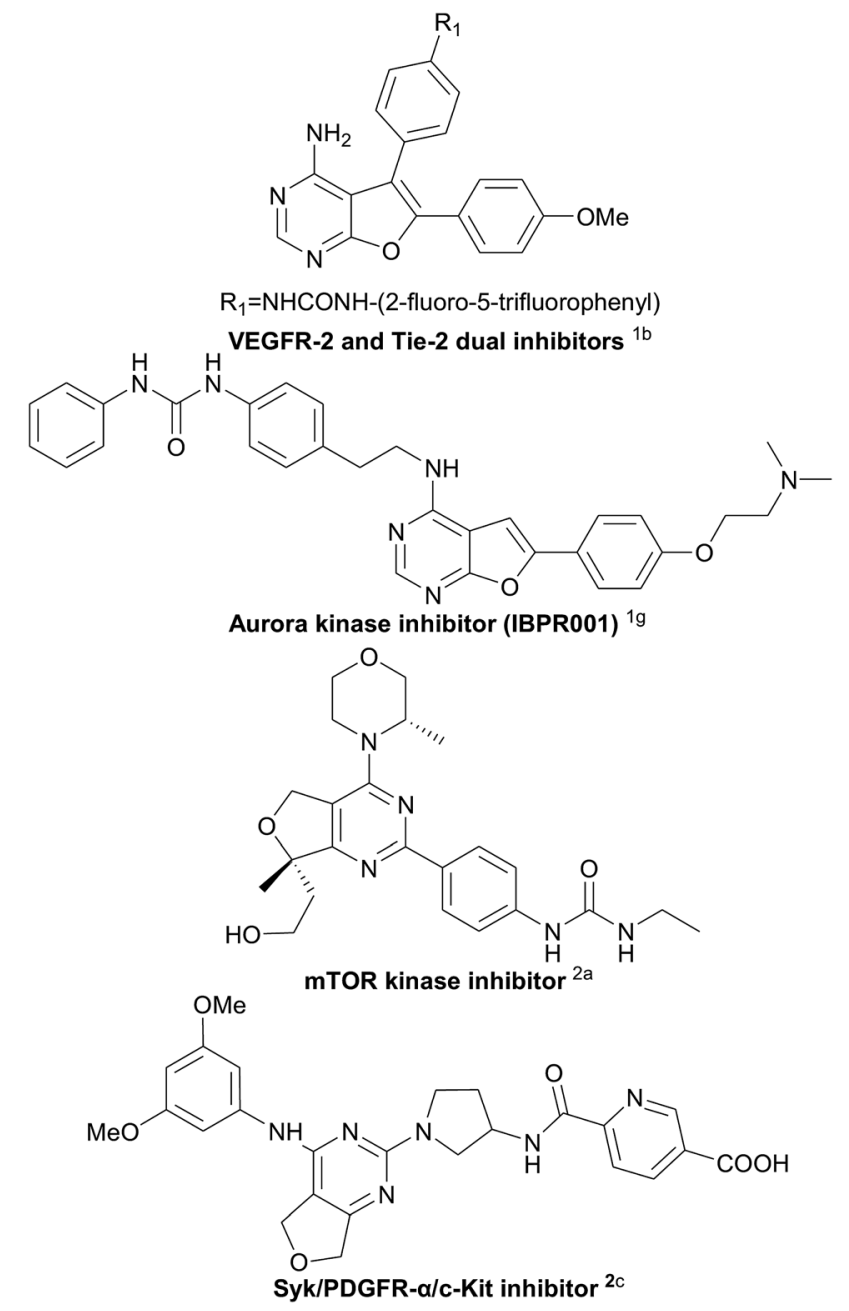

Scheme 1 Selected important biologically active heterocycles containing fused pyrimidine moieties. 

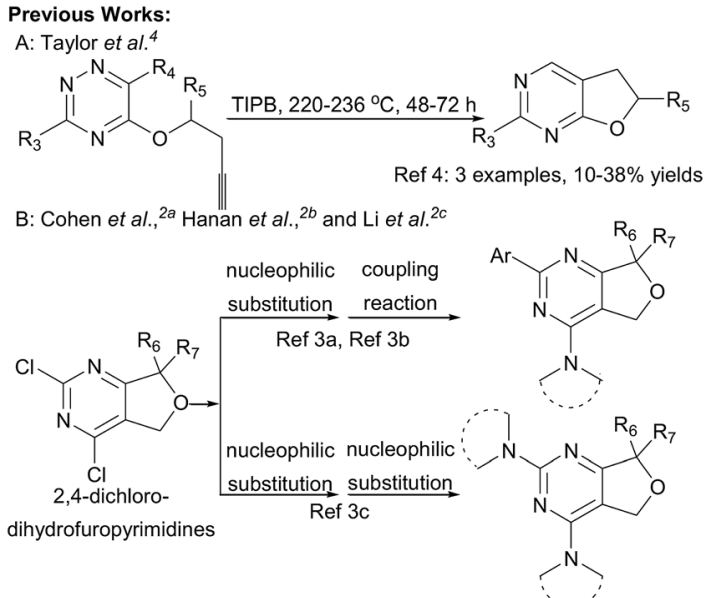

This Work

This Work:

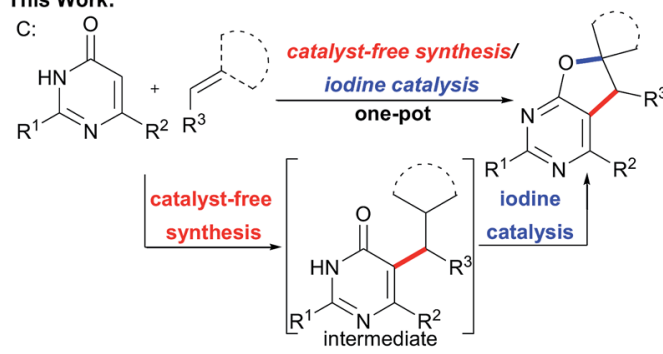

first example of merging catalyst-free synthesis and iodine catalysis simple operation, metal-free, and wide substrate tolerance high chemoselectivity

moderate to high yields and excellent diastereoselectivities

Scheme 2 General methods for the synthesis of dihydrofuropyrimidine derivatives.

materials, under simple and mild reaction conditions, and without the use of potentially toxic transition metals.

In past decades, catalyst-free synthesis has been extensively studied and applied to the construction of complex molecules, as it tends to be inexpensive and environmentally friendly. ${ }^{\mathbf{6 a , b , c}}$ For example, Deb, Baruah, and co-workers described two procedures for the synthesis of 1,3-oxazines ${ }^{6 \boldsymbol{d}}$ and pyrimidine ring compounds ${ }^{6 f}$ under the catalyst-free conditions. In 2017, the group of Brahmachari presented a catalyst-free protocol for the construction of functionalized pyridodipyrimidines. ${ }^{6 e}$ In recent years, iodine catalysis has also emerged as an efficient, metal-free methodology for chemical bond construction which has low toxicity, is environmentally benign, and is readily available. ${ }^{7}$ Very recently, we presented a new and efficient catalytic strategy that combined organocatalysis and iodine catalysis for the one-pot sequential catalytic synthesis of spirodihydrobenzofurans. ${ }^{8}$ The success of that approach suggested that it might be possible to prepare the biologically important dihydrofuro fused pyrimidines using a new strategy that combines catalyst-free synthesis and iodine catalysis. Herein, we report a facile and efficient methodology for the synthesis of dihydrofuro fused pyrimidine derivatives using 2,6-diaminopyrimidin-4(3H)-ones, ${ }^{9}$ versatile building blocks in organic synthesis which can be easily prepared, ${ }^{\mathbf{1 0}}$ nitroolefins, and unsaturated pyrazolones (Scheme 2C), in which the intermolecular reaction can be easily induced under very mild and catalyst free conditions, and the subsequent step of intramolecular cyclization can then be easily realized via iodine catalysis.

The one-pot reaction was initially performed with 2,6-diaminopyrimidin-4(3H)-one $\mathbf{1 a}$ and nitroolefin $\mathbf{2 a}$ as model substrates to demonstrate the feasibility of the designed approach. The overall synthesis proceeded smoothly, when the catalyst-free synthesis was conducted at $50{ }^{\circ} \mathrm{C}$ and the intramolecular cyclization was performed in the presence of $\mathrm{I}_{2}$ and tert-butyl hydroperoxide in $\mathrm{CH}_{3} \mathrm{CN}$ at room temperature, the reaction proceeded smoothly, affording the desired product $\mathbf{3 a}$ in $82 \%$ isolated yield (Table 1 , entry 1 ). A representative range of iodine sources were then tested for the second cyclization step (entries 2-6). The yield could be improved to $86 \%$ by using potassium iodide (entry 3). The second step was tested further using $\mathrm{KI}$ and a range of oxidants: TBPB, DTBP, $\mathrm{NaClO}_{2}, \mathrm{~K}_{2} \mathrm{~S}_{2} \mathrm{O}_{8}$, and even $\mathrm{H}_{2} \mathrm{O}_{2}$ (entries 7-11). Although the reaction tolerated

Table 1 Screening of reaction conditions ${ }^{a, g}$

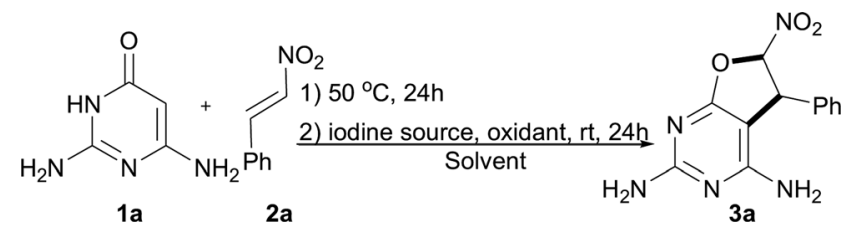

\begin{tabular}{|c|c|c|c|c|}
\hline Entry & Iodine source & Oxidant & Solvent & Yield $^{b}(\%)$ \\
\hline 1 & $\mathrm{I}_{2}$ & TBHP & $\mathrm{CH}_{3} \mathrm{CN}$ & 82 \\
\hline $2^{c}$ & $\mathrm{NaI}$ & TBHP & $\mathrm{CH}_{3} \mathrm{CN}$ & 84 \\
\hline $3^{c}$ & KI & TBHP & $\mathrm{CH}_{3} \mathrm{CN}$ & 86 \\
\hline $4^{c}$ & $\mathrm{NH}_{4} \mathrm{I}$ & TBHP & $\mathrm{CH}_{3} \mathrm{CN}$ & 72 \\
\hline $5^{c}$ & $n \mathrm{Bu}_{4} \mathrm{NI}$ & ТВНР & $\mathrm{CH}_{3} \mathrm{CN}$ & 80 \\
\hline $6^{c}$ & NIS & TBHP & $\mathrm{CH}_{3} \mathrm{CN}$ & 83 \\
\hline $7^{c}$ & $\mathrm{KI}$ & ТВPB & $\mathrm{CH}_{3} \mathrm{CN}$ & 54 \\
\hline $8^{c}$ & $\mathrm{KI}$ & DTBP & $\mathrm{CH}_{3} \mathrm{CN}$ & 23 \\
\hline $9^{c}$ & KI & $\mathrm{NaClO}_{2}$ & $\mathrm{CH}_{3} \mathrm{CN}$ & 28 \\
\hline $10^{c}$ & $\mathrm{KI}$ & $\mathrm{K}_{2} \mathrm{~S}_{2} \mathrm{O}_{8}$ & $\mathrm{CH}_{3} \mathrm{CN}$ & 32 \\
\hline $11^{c}$ & $\mathrm{KI}$ & $\mathrm{H}_{2} \mathrm{O}_{2}$ & $\mathrm{CH}_{3} \mathrm{CN}$ & 76 \\
\hline $12^{c}$ & KI & TBHP & DMF & Trace \\
\hline $13^{c}$ & $\mathrm{KI}$ & TBHP & THF & 82 \\
\hline $14^{c}$ & KI & TBHP & 1,4-Dioxane & Trace \\
\hline $15^{c}$ & KI & ТВHP & $\mathrm{MeOH}$ & 68 \\
\hline $16^{c}$ & KI & TBHP & $\mathrm{H}_{2} \mathrm{O}$ & 63 \\
\hline $17^{c, d}$ & KI & ТВHР & $\mathrm{CH}_{3} \mathrm{CN}$ & 55 \\
\hline $18^{c, e}$ & KI & TBHP & $\mathrm{CH}_{3} \mathrm{CN}$ & 73 \\
\hline $19^{c, f}$ & KI & TBHP & $\mathrm{MeOH}$ & 65 \\
\hline $20^{c, f}$ & $\mathrm{NH}_{4} \mathrm{I}$ & TBHP & $\mathrm{MeOH}$ & 50 \\
\hline $21^{c, f}$ & $n \mathrm{Bu}_{4} \mathrm{NI}$ & TBHP & $\mathrm{MeOH}$ & 70 \\
\hline $22^{c, f}$ & NIS & TBHP & $\mathrm{MeOH}$ & 52 \\
\hline $23^{c, f}$ & $n \mathrm{Bu}_{4} \mathrm{NI}$ & $\mathrm{H}_{2} \mathrm{O}_{2}$ & МеОН & 77 \\
\hline
\end{tabular}

${ }^{a}$ Unless otherwise stated, all the reactions were conducted in solvent (1 $\mathrm{mL})$ using $1 \mathrm{a}(0.1 \mathrm{mmol})$ and $2 \mathrm{a}(0.1 \mathrm{mmol})$ with stirring for $24 \mathrm{~h}$ at $50{ }^{\circ} \mathrm{C}$, this was followed by the addition of iodine source $(0.01 \mathrm{mmol})$ and oxidant $(0.2 \mathrm{mmol})$, and the solution was then stirred for $24 \mathrm{~h}$ at room temperature. ${ }^{b}$ Isolated yield. ${ }^{c}$ The reaction was conducted in the presence of $20 \mathrm{~mol} \%$ iodine source. ${ }^{d}$ First step was conducted at $40{ }^{\circ} \mathrm{C}$ for $24 \mathrm{~h}$. ${ }^{e}$ First step was conducted at $60^{\circ} \mathrm{C}$ for $24 \mathrm{~h} .{ }^{f}$ First step was conducted at room temperature for $24 \mathrm{~h}^{g}{ }^{g}$ The $\mathrm{dr}$ value is $>25: 1$ for all the isolated products. 
all of these oxidants, none produced as high a yield with $\mathrm{KI}$ as TBHP had. This combination was then examined in other solvents (entries 3 and 12-16) and it was found that $\mathrm{CH}_{3} \mathrm{CN}$ was best. With these optimal conditions in hand, further investigation was performed to study the influence of the reaction temperature on the catalyst-free synthesis step (entries 17-18). When the reaction was conducted at 40 or $60{ }^{\circ} \mathrm{C}$, the product $3 \mathrm{a}$ was obtained at $55 \%$ and $73 \%$ yields, respectively. Interestingly, at room temperature, the first catalyst-free synthesis step went

Table 2 Substrate scope for nitroolefins ${ }^{c, d}$

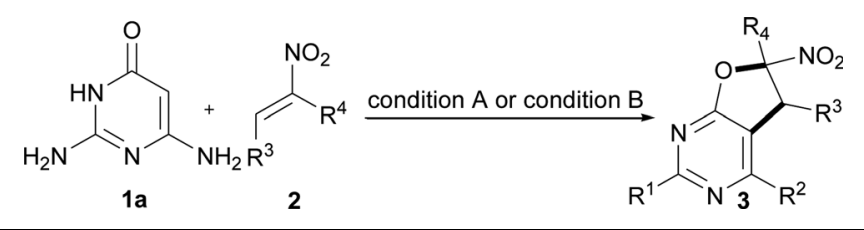

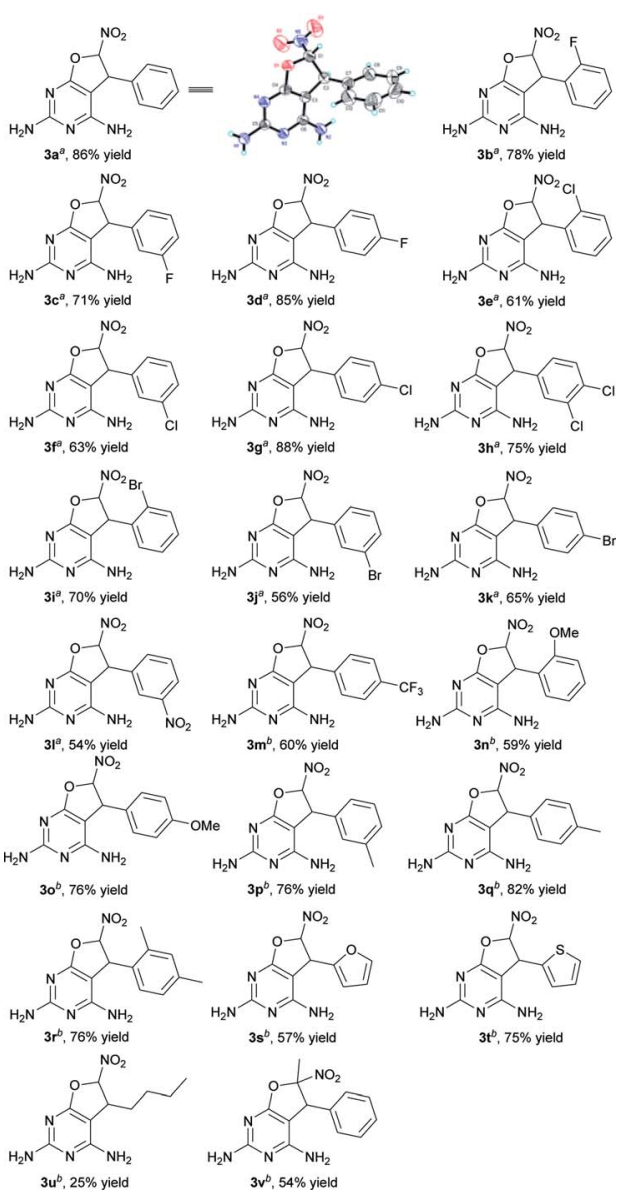

${ }^{a}$ Condition A: the reactions were conducted in $\mathrm{CH}_{3} \mathrm{CN}(1 \mathrm{~mL})$ using $\mathbf{1 a}$ $(0.1 \mathrm{mmol})$ and $2 \mathrm{a}(0.1 \mathrm{mmol})$ with stirring for $24 \mathrm{~h}$ at $50{ }^{\circ} \mathrm{C}$. This was followed by the addition of KI $(0.02 \mathrm{mmol})$ and TBHP $(0.2 \mathrm{mmol})$, and the solution was then stirred for $24 \mathrm{~h}$ at room temperature. ${ }^{b}$ Condition B: the reactions were conducted in $\mathrm{MeOH}(1 \mathrm{~mL})$ using $1 \mathrm{a}$ $(0.1 \mathrm{mmol})$ and $2 \mathrm{a}(0.1 \mathrm{mmol})$ with stirring for $24 \mathrm{~h}$ at room temperature. This was followed by the addition of $n \mathrm{Bu}_{4} \mathrm{NI}(0.02 \mathrm{mmol})$ and $\mathrm{H}_{2} \mathrm{O}_{2}(0.2 \mathrm{mmol})$, and the solution was then stirred for $24 \mathrm{~h}$ at room temperature. ${ }^{c}$ Isolated yield. ${ }^{d}$ The $\mathrm{dr}$ value is $>25: 1$ for all the products. well in $\mathrm{MeOH}$ to give the final product 3a in 65\% yield (entry 19). Further screening of the reaction conditions (entries 20-23) showed that the combination of TBAI and $\mathrm{H}_{2} \mathrm{O}_{2}$ in the second step, at room temperature, afforded product $3 \mathbf{a}$ in $77 \%$ yield (entry 23).

With the optimized conditions in hand, the substrate scope was then investigated (Table 2). ${ }^{\mathbf{1 1}}$ The reaction was found to be compatible with nitroolefins bearing both electron-withdrawing and electron-donating groups. Substrates with electronwithdrawing substituent groups, such as $\mathrm{F}, \mathrm{Cl}, \mathrm{Br}, \mathrm{NO}_{2}$, or $\mathrm{CF}_{3}$ on the phenyl ring, afforded moderate to high yields, ranging from $54 \%$ to $88 \%(3 \mathbf{b}-\mathbf{m})$. It was worth noting that, at room temperature, nitroalkenes bearing electron-rich motifs such as $\mathrm{MeO}$, or Me on the phenyl core, heterocyclic nitroolefins, an aliphatic nitroolefin and $\alpha$-methyl-substituted nitroolefin all tolerated this transformation, producing the desired dihydrofuropyrimidines in $25 \%$ to $82 \%$ yields (3n-v). For example, by using heterocyclic nitroolefins, products $3 \mathbf{s}$ and $3 \mathbf{t}$ were obtained in $57 \%$ and $75 \%$ yields, respectively. Aliphatic nitroolefin bearing a butyl group provided $3 \mathbf{u}$ in $25 \%$ yield. Furthermore, the $\alpha$-methyl-substituted nitroolefin was also able to participate in this transformation to afford product $3 \mathbf{v}$ with $54 \%$ yield.

Having successfully synthesized an array of dihydrofuropyrimidines, attention was next turned toward the synthesis of biologically interesting spirodihydrofuropyrimidines. In the

Table 3 Screening of reaction conditions ${ }^{a f}$

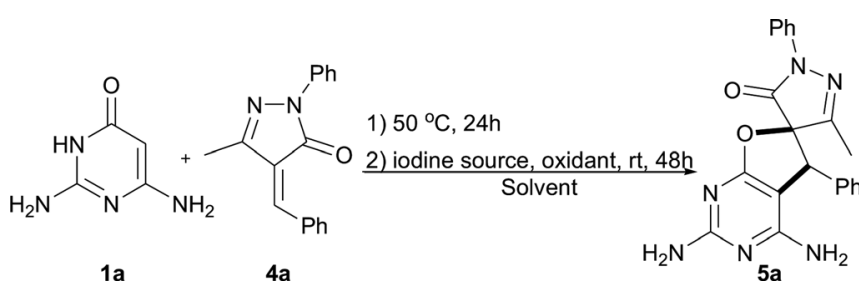

\begin{tabular}{|c|c|c|c|c|}
\hline Entry & Iodine source & Oxidant & Solvent & Yield $^{b}(\%)$ \\
\hline 1 & KI & $\mathrm{O}_{2}$ & $\mathrm{CH}_{3} \mathrm{CN}$ & 4 \\
\hline 2 & KI & $\mathrm{O}_{2}$ & 1,4-Dioxane & 91 \\
\hline 3 & KI & Open air & 1,4-Dioxane & 90 \\
\hline 4 & TBAI & Open air & 1,4-Dioxane & 85 \\
\hline $5^{c}$ & $\mathbf{I}_{2}$ & Open air & 1,4-Dioxane & 96 \\
\hline 6 & NIS & Open air & 1,4-Dioxane & 78 \\
\hline $7^{c}$ & $\mathrm{I}_{2}$ & Open air & THF & 45 \\
\hline $8^{c}$ & $\mathrm{I}_{2}$ & Open air & Isopropyl ether & 4 \\
\hline $9^{c}$ & $\mathrm{I}_{2}$ & Open air & EtOAc & Trace \\
\hline $10^{c}$ & $\mathrm{I}_{2}$ & Open air & $\mathrm{CH}_{3} \mathrm{CN}$ & 66 \\
\hline $11^{c}$ & $\mathrm{I}_{2}$ & Open air & $\mathrm{MeOH}$ & Trace \\
\hline $12^{c}$ & $\mathrm{I}_{2}$ & Open air & $\mathrm{H}_{2} \mathrm{O}$ & 22 \\
\hline $13^{c, d}$ & $\mathrm{I}_{2}$ & Open air & 1,4-Dioxane & 80 \\
\hline $14^{c, e}$ & $\mathrm{I}_{2}$ & Open air & 1,4-Dioxane & 90 \\
\hline
\end{tabular}

${ }^{a}$ Unless otherwise stated, all the reactions were conducted in solvent (1 $\mathrm{mL})$ using $1 \mathrm{a}(0.12 \mathrm{mmol})$ and $4 \mathrm{a}(0.1 \mathrm{mmol})$ with stirring for $24 \mathrm{~h}$ at $50{ }^{\circ} \mathrm{C}$. This was followed by the addition of iodine source $(0.02 \mathrm{mmol})$ and oxidant $\left(\mathrm{O}_{2}\right.$ balloon), and the solution was then stirred for $48 \mathrm{~h}$ at room temperature. ${ }^{b}$ Isolated yield. ${ }^{c}$ The reaction was conducted in the presence of $10 \mathrm{~mol} \%$ iodine source. ${ }^{d}$ First step was conducted at $40{ }^{\circ} \mathrm{C}$ for $24 \mathrm{~h} .{ }^{e}$ First step was conducted at $60^{\circ} \mathrm{C}$ for $24 \mathrm{~h} .{ }^{f}$ The $\mathrm{dr}$ value is $>25: 1$ for all the isolated products. 
Table 4 Substrate scope of the spirodihydrofuropyrimidine formation reaction ${ }^{a}$

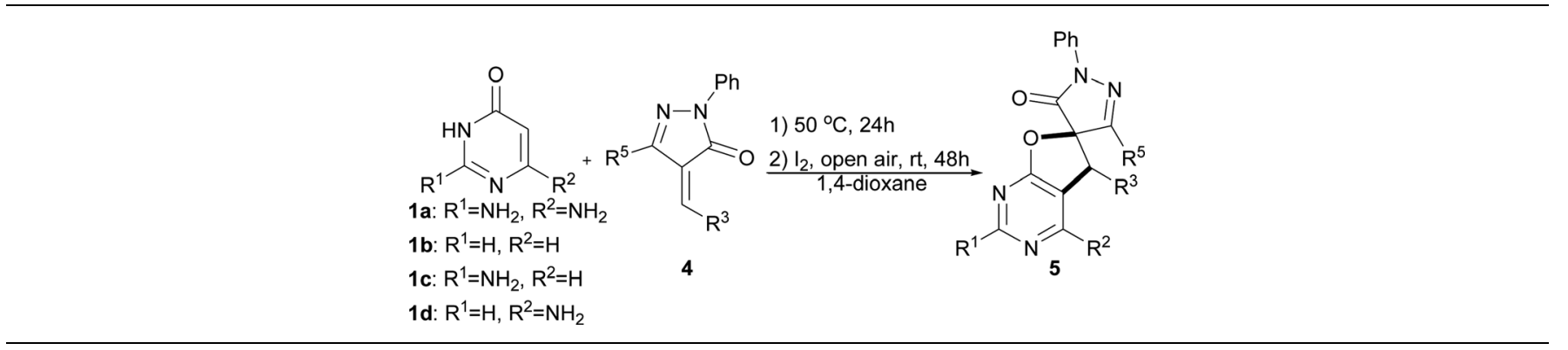

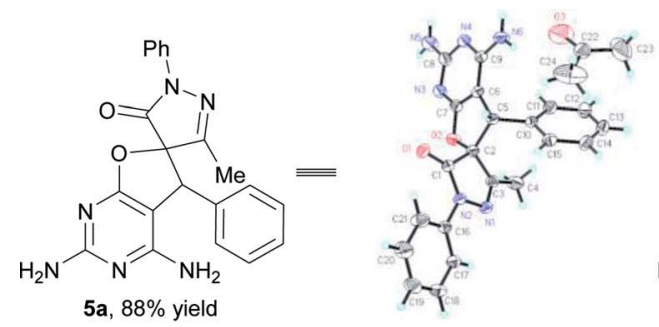

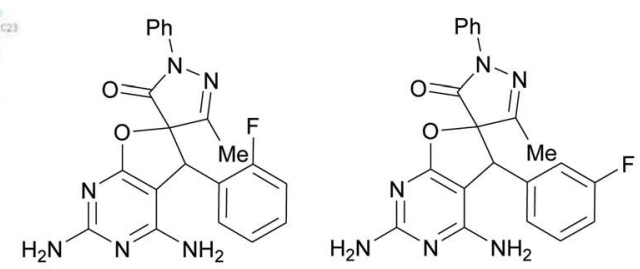

5b, $95 \%$ yield
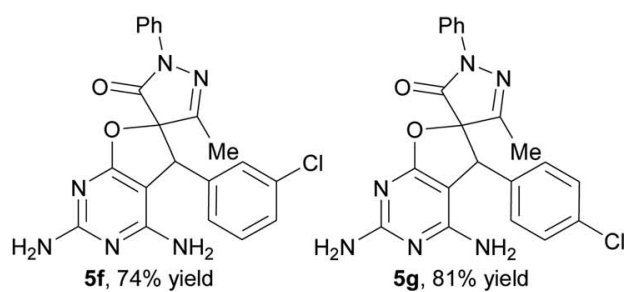

5c, $96 \%$ yield<smiles>Nc1nc(N)c2c(n1)OC1(C(=O)N(c3ccccc3)N=C1c1ccc(F)cc1)C2c1ccccc1</smiles><smiles></smiles>

5e, $96 \%$ yield<smiles>Nc1nc(N)c2c(n1)OC1(C2=O)C(=O)N(c2ccccc2)N=C1c1ccc(Br)cc1</smiles><smiles>CC1=NN(c2ccccc2)C(=O)C12Oc1nc(I)nc(N)c1C2c1cccc([N+](=O)[O-])c1</smiles>

5I, $77 \%$ yield<smiles>NCCCCN</smiles>

5d, $88 \%$ yield<smiles>Nc1cc(Cl)c(C2c3c(N)nc(N)nc3OC2(c2nn(-c3ccccc3)c(=O)[nH]2)C(Cl)Cl)c(N)n1</smiles><smiles>Nc1cc(N)c2c(n1)OC1(C(=O)N(c3ccccc3)N=C1Br)C2c1ccccc1Br</smiles><smiles></smiles>

$\mathbf{5 k}, 95 \%$ yield<smiles>Cc1ccc(C2N=C(N)C3(Oc4nc(N)nc(N)c42)C(c2ccccc2)N3c2ccccc2)cc1</smiles>
5 p, $50 \%$ yield<smiles></smiles>

$$
5 u, \text { n.d }
$$<smiles>CC1=NN(c2ccccc2)C(=O)C12Oc1nc(N)nc(N)c1C2c1cccc([18OH])c1</smiles><smiles></smiles><smiles></smiles>

5q, $85 \%$ yield<smiles>[M]C1=NN(c2ccccc2)C(=O)C12Oc1ncnc(N)c1C2c1ccccc1</smiles>

${ }^{a}$ All the reactions were conducted in 1,4-dioxane $(1 \mathrm{~mL})$ using $\mathbf{1}(0.12 \mathrm{mmol})$ and $\mathbf{4}(0.1 \mathrm{mmol})$ with stirring for $24 \mathrm{~h}$ at $50{ }^{\circ} \mathrm{C}$. This was followed by the addition of $\mathrm{I}_{2}(0.01 \mathrm{mmol})$ under open air condition, and the solution was then stirred for $48 \mathrm{~h}$ at room temperature. Stated yields are isolated yields. The dr value is $>25: 1$ for all the products. 
<smiles></smiles><smiles>CC1=NN(c2ccccc2)C(=O)C1=Cc1ccccc1</smiles>

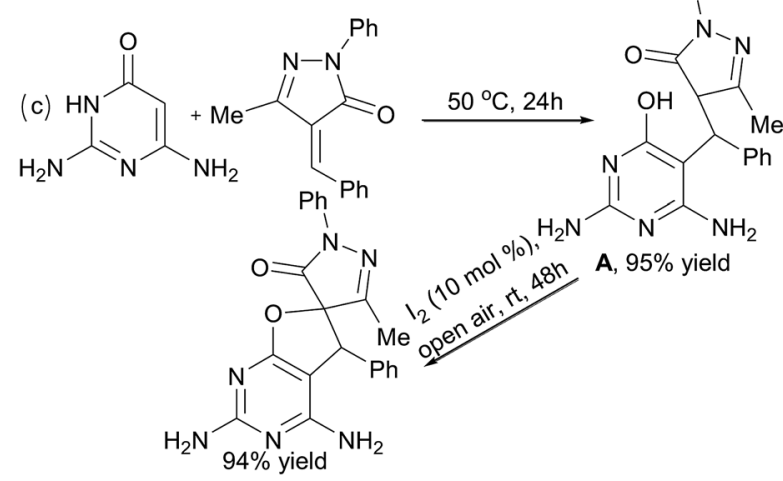

Scheme 3 Mechanistic studies.

previous study, it was discovered that 2,6-diaminopyrimidin$4(3 H)$-one 1a could react with unsaturated pyrazolone $4 a$ to form a spirodihydrofuropyrimidine $\mathbf{5 a}$ in $4-91 \%$ yields under oxygen atmosphere (Table 3, entries 1 and 2). These results suggested a unique opportunity to develop an one-pot approach for the synthesis of spirodihydrofuropyrimidines in an open air atmosphere. Then iodine sources and solvents were screened with these starting materials (1a and $\mathbf{4 a}$ ) to optimize the reaction outcome under open air conditions (entries 3-12). The best result was obtained (entry $5,96 \%$ yield) when $I_{2}$ was utilized as iodine source and 1,4-dioxane was used as the solvent. Next, the influence of temperature on the reaction outcome was studied. The desired product $5 \mathrm{a}$ was produced in $80 \%$ and $90 \%$ yields when the reaction mixture was heated at 40 and $60{ }^{\circ} \mathrm{C}$, respectively (entries 13 and 14).

Next, the scope of the spirodihydrofuropyrimidine formation reaction was explored with pyrimidin-4(3H)-ones $\mathbf{1}$ and a wide variety of unsaturated pyrazolones 4 (Table 4). ${ }^{11}$ Initially, a number of unsaturated pyrazolones $\mathbf{5}$ were subjected to the reaction under optimized conditions. In general, a variety of unsaturated pyrazolones bearing both electron-withdrawing $(\mathrm{F}$, $\mathrm{Cl}, \mathrm{Br}$, and $\mathrm{NO}_{2}$ ) and electron-donating ( $\mathrm{Me}$ and $\mathrm{MeO}$ ) groups at the phenyl ring were found to be suitable for the reaction, providing the corresponding spirodihydrofuropyrimidines $\mathbf{5 a -}$ $5 \mathbf{r}$ in moderate to excellent yields $(50-96 \%)$. The reaction of unsaturated pyrazolone containing an ethyl group substitution on the pyrazolone ring proceeded smoothly to afford the desired product $5 \mathrm{~s}$ in $74 \%$ yield. Subsequently, to establish the generality of the one-pot reaction, some other amino substituted pyrimidin-4(3H)-ones were also employed under the optimized reaction conditions. When pyrimidin-4(3H)-one $\mathbf{1 b}$ and $\mathbf{1} \mathbf{c}$ were introduced as partners with unsaturated pyrazolone $\mathbf{4 a}$, respectively, the desired products $\mathbf{5 t}$ and $\mathbf{5 u}$ were not formed, because the first step of catalyst-free synthesis did not take place. Substrate 1d reacted well and furnished the spirodihydrofuropyrimidine $\mathbf{5 v}$ in $30 \%$ yield.

To understand the mechanism of the reaction, some control experiments were performed under modified conditions in 1,4dioxane (Scheme 3). High yields could still be obtained in the presence of radical scavenger (TEMPO) (Scheme 3a) or under dark conditions for the second $\mathrm{I}_{2}$-catalyzed step (Scheme $3 \mathrm{~b}$ ). Thus, a radical mechanism could be excluded for this kind of transformation. Next, when the product of the first catalyst-free synthesis step, intermediate $\mathbf{A}$, was separated and used for the

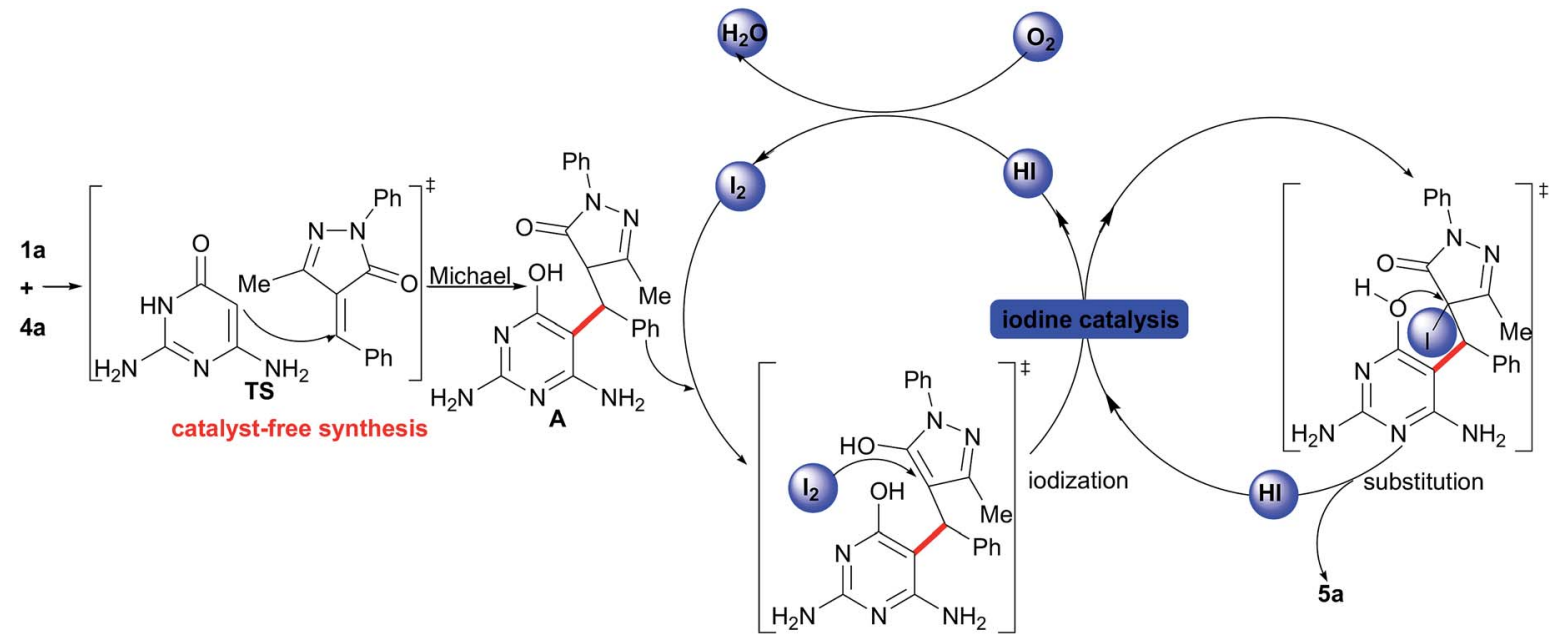

Scheme 4 A proposed mechanism for the one-pot reaction. 
$\mathrm{I}_{2}$-catalyzed step under the standard conditions, compound 5a was obtained in $89 \%$ yield (Scheme 3c).

Then, based on the aforementioned studies, ${ }^{8}$ a presumptive mechanism for the synthesis of dihydrofuropyrimidines from 2,6-diaminopyrimidin-4(3H)-ones and unsaturated pyrazolones is proposed (Scheme 4). The initial step should be a catalyst-free Michael addition of 1a to $\mathbf{4 a}$, which generates an intermediate $\mathbf{A}$ via a transition state (TS). Then, this intermediate $\mathbf{A}$ can be transformed into 5 a through the $\mathrm{I}_{2}$-catalyzed cyclization (via the iodization reaction and then the nucleophilic substitution). Finally, the HI reacts with $\mathrm{O}_{2}$ to give $\mathrm{I}_{2}$ for the next cycle.

\section{Conclusions}

In summary, a novel strategy that combines catalyst-free synthesis and iodine catalysis in the presence of oxidant was developed for the one-pot synthesis of dihydrofuropyrimidines and spirodihydrofuropyrimidine pyrazolones from 2,6-diaminopyrimidin-4(3H)-ones, nitroolefins, and unsaturated pyrazolones. Dihydrofuro fused pyrimidine derivatives were synthesized in moderate to good yields with excellent diastereoselectivities using TBHP, or $\mathrm{H}_{2} \mathrm{O}_{2}$ as the oxidants. Spirodihydrofuropyrimidine pyrazolones were produced in high to excellent yields with good functional group tolerance and excellent diastereoselectivities under open air conditions (molecular oxygen as the oxidant). This reaction features simple operation and is metal-free. Further studies on the applications of this methodology to organic synthesis are ongoing in our laboratory.

\section{Conflicts of interest}

There are no conflicts to declare.

\section{Acknowledgements}

This work was financially supported by the Zhejiang Natural Science Foundation (LY18B020017), Zhejiang Key Laboratory of Green Pesticides and Cleaner Production Technology.

\section{Notes and references}

1 For selected examples, see: (a) A. Gangjee, X. Guo, S. F. Queener, V. Cody, N. Galitsky, J. R. Luft and W. Pangborn, J. Med. Chem., 1998, 41, 1263; (b) Y. Miyazaki, S. Matsunaga, J. Tang, Y. Maeda, M. Nakano, R. J. Philippe, M. Shibahara, W. Liu, H. Sato, L. Wang and R. T. Nolte, Bioorg. Med. Chem. Lett., 2005, 15, 2203; (c) A. Gangjee, Y. Zeng, M. Ihnat, L. A. Warnke, D. W. Green, R. L. Kisliuk and F. T. Lin, Bioorg. Med. Chem., 2005, 13, 5475; (d) Y. Miyazaki, J. Tang, Y. Maeda, M. Nakano, L. Wang, R. T. Nolte, H. Sato, M. Sugai, Y. Okamoto, A. T. Truesdale, D. F. Hassler, E. N. Nartey, D. R. Patrick, M. L. Ho and K. Ozawa, Bioorg. Med. Chem. Lett., 2007, 17, 1773; (e) E. F. DiMauro, J. Newcomb, J. J. Nunes, J. E. Bemis, C. Boucher, J. L. Buchanan, W. H. Buckner, A. Cheng, T. Faust, F. Hsieh, X. Huang, J. H. Lee,
T. L. Marshall, M. W. Martin, D. C. McGowan, S. Schneider, S. M. Turci, R. D. White and X. Zhu, Bioorg. Med. Chem. Lett., 2007, 17, 2305; (f) Y. Miyazaki, Y. Maeda, H. Sato, M. Nakano and G. W. Mellor, Bioorg. Med. Chem. Lett., 2008, 18, 1967; (g) H.-Y. Shiao, M. S. Coumar, C.-W. Chang, Y.-Y. Ke, Y.-H. Chi, C.-Y. Chu, H.-Y. Sun, C.-H. Chen, W.-H. Lin, K.-S. Fung, P.-C. Kuo, C.-T. Huang, K.-Y. Chang, C.-T. Lu, J. T. A. Hsu, C.-T. Chen, W.-T. Jiaang, Y.-S. Chao and H.-P. Hsieh, J. Med. Chem., 2013, 56, 5247.

2 (a) F. Cohen, P. Bergeron, E. Blackwood, K. K. Bowman, H. Chen, A. G. DiPasquale, J. A. Epler, M. F. T. Koehler, K. Lau, C. Lewis, L. Liu, C. Q. Ly, S. Malek, J. Nonomiya, D. F. Ortwine, Z. Pei, K. D. Robarge, S. Sideris, L. Trinh, T. Truong, J. Wu, X. Zhao and J. P. Lyssikatos, J. Med. Chem., 2011, 54, 3426; (b) E. J. Hanan, M. Baumgardner, M. C. Bryan, Y. Chen, C. Eigenbrot, P. Fan, X.-H. Gu, H. La, S. Malek, H. E. Purkey, G. Schaefer, S. Schmidt, S. Sideris, I. Yen, C. Yu and T. P. Heffron, Bioorg. Med. Chem. Lett., 2016, 26, 534; (c) X. Li, Y. Huang, J. Cheng, L. Zhang, F. Mao, J. Zhu, C. Sheng and J. Li, Bioorg. Med. Chem., 2018, 26, 4375.

3 (a) J. Teixidó, J. I. Borrell, C. Colominas, X. Deupí, J. L. Matallana, J. L. Falcó and B. Martinez-Teipel, J. Org. Chem., 2001, 66, 192; (b) A. Rosowsky, R. A. Forsch and S. F. Queener, J. Med. Chem., 2002, 45, 233; (c) Y. Deng, Y. Wang, C. Cherian, Z. Hou, S. A. Buck, L. H. Matherly and A. Gangjee, J. Med. Chem., 2008, 51, 5052; (d) M. Mannaghani and R. H. Nia, J. Heterocycl. Chem., 2017, 54, 1700.

4 E. C. Taylor and J. L. Pont, J. Org. Chem., 1987, 52, 4287.

5 (a) P. Bergeron, F. Cohen, A. Estrada, M. Koehler, W. Lee, C. Ly, J. Lyssikatos, Z. Pei and X. Zhao, PCT Int. Appl., 2010151601, 2010; (b) K. M. Boy, J. M. Guernon, J. E. Macor, R. E. Olson, J. Shi, L. A. Thompson, Y.-J. Wu, L. Xu, Y. Zhang and D. S. Zuev, PCT Int. Appl., 2011014535, 2011; (c) B.-K. Kim, J.-H. Lui, B.-K. Lee, O. H. Kwon, Y.-K. Kim, C.-W. Kim, H.-S. Kim, J.-H. Seo, C.-J. Shin, E.-S. Yu, S.-J. Lee, B. K. Choi and K. Y. Hwang, PCT Int. Appl., 2015105316, 2015; (d) H.-J. Zhou and W. David, US Pat., 9828363B2, 2017; (e) S.-S. Lee and D.-M. Kang, Eur. Pat., 3056498B1, 2018.

6 For selected reviews, see: (a) M. B. Gawande, V. D. Bonifácio, R. Luque, P. S. Branco and R. S. Varma, Chem. Soc. Rev., 2013, 42, 5522; (b) M. B. Gawande, V. D. Bonifácio, R. Luque, P. S. Branco and R. S. Varma, ChemSusChem, 2014, 7, 24; (c) A. Sarkar, S. Santra, S. K. Kundu, A. Hajra, G. V. Zyryanov, O. N. Chupakhin, V. N. Charushin and A. Majee, Green Chem., 2016, 18, 4475For selected examples, see: (d) M. L. Deb, C. D. Pegu, P. J. Borpatra, P. J. Saikia and P. K. Baruah, Green Chem., 2017, 19, 4036; (e) G. Brahmachari, K. Nurjamal, I. Karmakar, S. Begam, N. Nayek and B. Mandal, ACS Sustainable Chem. Eng., 2017, 5, 9494; (f) M. L. Deb, P. J. Borpatra and P. K. Baruah, Green Chem., 2019, 21, 69.

7 For selected reviews, see: $(a)$ A. N. French, S. Bissmire and T. Wirth, Chem. Soc. Rev., 2004, 33, 354; (b) P. T. Parvatkar, 
P. S. Parameswaran and S. G. Tilve, Chem.-Eur. J., 2012, 18, 5460; (c) D. Liu and A. Lei, Chem.-Asian J., 2015, 10, 806; (d) A. Yoshimura and V. V. Zhdankin, Chem. Rev., 2016, 116, 3328for selected examples, see: (e) R. Yan, X. Li, X. Yang, X. Kang, L. Xiang and G. Huang, Chem. Commun., 2015, 51, 2573; (f) G.-W. Wang and J. Gao, Org. Lett., 2009, 11, 2385.

8 C.-K. Tang, Z.-Y. Zhou, A.-B. Xia, L. Bai, J. Liu, D.-Q. Xu and Z.-Y. Xu, Org. Lett., 2018, 20, 5840.

9 For selected recent representative advances based on 2,6diaminopyrimidin-4(3H)-one, see: (a) F. Zhang, C. Li and X. Liang, Green Chem., 2018, 20, 2057; (b) C. Li and
F. Zhang, Synlett, 2017, 28, 1315; (c) M. Camarasa, C. Barnils, R. P. Bellacasa, J. Teixidó and J. I. Borrell, Mol. Diversity, 2013, 17, 525.

10 (a) F. Ye, L. Chen, L. Hu, T. Xiao, S. Yu, D. Chen, Y. Wang, G. Liang, Z. Liu and S. Wang, Bioorg. Med. Chem. Lett., 2015, 25, 1556; (b) V. E. Saraev, I. M. Zviagin, R. G. MelikOganjanyan, Y. V. Sen'ko, S. M. Desenko and V. A. Chebanov, J. Heterocycl. Chem., 2017, 54, 318.

11 CCDC 1893720 contains the supplementary crystallographic data for compound 4a and CCDC 1893721 contains the supplementary crystallographic data for compound $\mathbf{5 a} . \dagger$ 